\title{
Development of a Thermodynamic Database for Mold Flux and Application to the Continuous Casting Process
}

\author{
Marie-Aline VAN ENDE and In-Ho JUNG* \\ Department of Mining and Materials Engineering, McGill University, 3610 University Street, Montreal, QC H3A 0C5 Canada. \\ (Received on August 30, 2013; accepted on January 7, 2014)
}

\begin{abstract}
A thermodynamic database for the oxyfluoride system $\mathrm{CaO}-\mathrm{MgO}-\mathrm{Al}_{2} \mathrm{O}_{3}-\mathrm{SiO}_{2}-\mathrm{Na}_{2} \mathrm{O}-\mathrm{K}_{2} \mathrm{O}-\mathrm{Li}_{2} \mathrm{O}-\mathrm{MnO}-$ $\mathrm{FeO}-\mathrm{F}$ has been developed based on the critical evaluation and optimization of all available experimental thermodynamic and phase diagram data. The developed database can be used for phase diagram and equilibrium solidification calculations for multicomponent systems. Such accurate database with high predictability capability assists in understanding the crystallization behavior of mold fluxes. In addition, a kinetic model was developed to simulate the interactions between the mold flux and molten steel using effective equilibrium reaction volumes combined with the thermodynamic database. The kinetic model successfully reproduced the significant $\mathrm{Al}_{2} \mathrm{O}_{3}$ accumulation observed when casting high $\mathrm{Al}$ steel with $\mathrm{CaO}-\mathrm{SiO}_{2}$ based mold flux. Equilibrium solidification calculation performed on the $\mathrm{Al}_{2} \mathrm{O}_{3}$-rich mold slag revealed detrimental changes in the solidification temperature, the primary phase and the evolution of the liquid fraction with temperature.
\end{abstract}

KEY WORDS: continuous casting mold flux; thermodynamic database; equilibrium solidification behavior; kinetic model; steel/slag/inclusion reactions.

\section{Introduction}

Mold fluxes play a crucial role during the continuous casting of steel: $:^{1)}$ they prevent steel reoxidation and freezing of the steel surface, absorb non-metallic inclusions, control horizontal heat transfer and provide lubrication throughout the strand. The two last functions are considered the most important and require adequate physicochemical properties of the mold powder such as viscosity, crystallization behavior, crystalline fraction of the slag film, interfacial tension, thermal properties of the solid and liquid phases, etc. A wrong choice of mold powder can lead to defects such as longitudinal cracking and sticker breakouts, along with process problems. Typical mold fluxes belong to the $\mathrm{CaO}-$ $\mathrm{SiO}_{2}-\mathrm{Al}_{2} \mathrm{O}_{3}-\mathrm{Na}_{2} \mathrm{O}-\mathrm{F}$ system with small addition of $\mathrm{MgO}$, $\mathrm{K}_{2} \mathrm{O}$ and $\mathrm{Li}_{2} \mathrm{O}$. A small amount of $\mathrm{FeO}, \mathrm{Fe}_{2} \mathrm{O}_{3}$ and $\mathrm{MnO}$ can be picked up in the mold slag through reaction with liquid steel. Although the general effects of each mold flux component on relevant mold flux properties are known, ${ }^{1)}$ determining the optimum mold flux composition for a given plant generally requires a trial-and-error approach. A successful mold powder in one plant often may not provide the same performance in another plant due to the differences in casting conditions, mold dimensions, steel grades and variability in casting conditions between each plant. Casting a

\footnotetext{
This article is one which was originally scheduled for publication in the special issue (Vol. 54, No. 2) on "Cutting Edge of Computer Simulation of Solidification, Casting and Refining" and instead was specially published in this regular issue.

* Corresponding author: E-mail: in-ho.jung@mcgill.ca DOI: http://dx.doi.org/10.2355/isijinternational.54.489
}

new steel grade will usually require the development of a new mold flux, which can become expensive and time consuming with such approach. Moreover, severe continuous casting process difficulties arise when large reactions take place between molten mold flux, molten steel and nonmetallic inclusions. These reactions may cause significant compositional changes of the molten mold flux, which induce variations in mold flux properties and performance. This phenomenon was observed when casting high Al steels with conventional $\mathrm{CaO}-\mathrm{SiO}_{2}$ based mold fluxes, ${ }^{2,3)}$ resulting in a significant $\mathrm{Al}_{2} \mathrm{O}_{3}$ accumulation (25 to $35 \mathrm{wt} \% \mathrm{Al}_{2} \mathrm{O}_{3}$ within $15 \mathrm{~min}^{2,3)}$ ) and $\mathrm{SiO}_{2}$ reduction in the mold flux.

In spite of their industrial importance, the phase equilibrium of fluorine containing oxide systems has not been well investigated due to the complexity of their chemistry and the difficulties in performing experiments. No systematic thermodynamic modeling of these systems has been conducted to date, either.

In order to assist in the design of mold flux for the continuous casting process and fluxes for special refining processes, a thermodynamic database for the oxyfluoride system containing $\mathrm{CaO}-\mathrm{MgO}-\mathrm{Al}_{2} \mathrm{O}_{3}-\mathrm{SiO}_{2}-\mathrm{Na}_{2} \mathrm{O}-\mathrm{K}_{2} \mathrm{O}-\mathrm{Li}_{2} \mathrm{O}-$ $\mathrm{MnO}-\mathrm{FeO}-\mathrm{F}$ has been developed by our research group for many years. Such database gives precious information on the solidification behavior of a given mold flux, which is of great help to understand its performance and provide candidates for new mold flux design, thereby surpassing the conventional trial-and-error approach. In the present study, the recent thermodynamic database for the oxyfluroide system will be overviewed. Then, a kinetic model, developed to calculate the change in composition in mold slag during con- 
tinuous casting by considering the reactions between molten mold flux and steel, and the absorption of non-metallic inclusions, is presented. The model combines the thermodynamic database and kinetics and aims at predicting the evolution of the mold flux composition under various casting conditions and operations, and assisting in understanding the reasons for this evolution.

\section{Thermodynamic Database Development for Mold Flux}

\subsection{Thermodynamic Model}

A thermodynamic database for the mold flux system $\left.\mathrm{CaO}-\mathrm{MgO}-\mathrm{Al}_{2} \mathrm{O}_{3}-\mathrm{SiO}_{2}-\mathrm{Na}_{2} \mathrm{O}-\mathrm{K}_{2} \mathrm{O}-\mathrm{Li}_{2} \mathrm{O}-\mathrm{MnO}-\mathrm{FeO}-\mathrm{F}^{4-7}\right)$ was built based on the critical evaluation and thermodynamic optimisation of all reliable experimental thermodynamic and phase diagram data found in literature. Each binary, ternary and multicomponent system was optimised systematically and key experiments ${ }^{8)}$ were performed to resolve inconsistencies in literature data. One set of model equation for the Gibbs energies was obtained for all solid and liquid phases as functions of temperature and composition. Based on these equations, any thermodynamic properties and phase diagram can be back-calculated, rendering all the data self-consistent and coherent with thermodynamic principles. Discrepancies in available data can often be resolved, and interpolation and extrapolation can be made in a thermodynamically correct manner. In this way, a consistent and accurate database with high predictability capability can be obtained.

The thermodynamic properties of the liquid oxide phase have been well described by the Modified Quasichemical Model, ${ }^{9,10)}$ which takes into account short range ordering of second nearest neighbor atoms. This short range ordering can be considered using bridging, broken and free oxygen atoms in the silicate structure. The Modified Quasichemical Model has already been applied successfully to numerous liquid oxide systems such as $\mathrm{CaO}-\mathrm{Al}_{2} \mathrm{O}_{3}-\mathrm{SiO}_{2}-\mathrm{MgO}-\mathrm{FeO}-$ $\mathrm{Fe}_{2} \mathrm{O}_{3},{ }^{11-17)}$ and is at the basis of the FactSage FToxid slag database $^{18)}$ for multicomponent oxide melts. When both oxygen and fluorine exist together in the melt, the short range ordering of both first- and second-nearest neighbor atoms has to be considered. Therefore, the oxyfluoride liquid phase was described using the two-sublattice Modified Quasichemical Model, ${ }^{19)}$ in which cations such as $\mathrm{Ca}^{2+}, \mathrm{Si}^{4+}$, $\mathrm{Al}^{3+}, \mathrm{Na}^{+}$, etc. occupy the first imaginary sublattice in the melt and anions such as $\mathrm{O}^{2-}$ and $\mathrm{F}^{-}$the second imaginary sublattice. The two-sublattice Modified Quasichemical Model allows taking into account the short-range ordering and reciprocal exchange reaction of cations and anions in the oxyfluoride slag. In the next section, a brief description of the thermodynamic optimization of the $\mathrm{CaO}-\mathrm{SiO}_{2}-\mathrm{CaF}_{2}$ system, which is the basis of conventional mold fluxes, is given. All thermodynamic and phase diagram calculations were made with FactSage software version 6.3, ${ }^{18)}$ which contains a Gibbs energy minimization routine.

\subsection{Thermodynamic Modeling of the $\mathrm{CaO}-\mathrm{SiO}_{2}-\mathrm{CaF}_{2}$ System}

The $\mathrm{CaO}-\mathrm{SiO}_{2}-\mathrm{CaF}_{2}$ system has been studied extensively with various techniques since it is at the basis of welding fluxes, slags, mold fluxes, refractory ceramics and cement.
In the present study, the experimental phase diagram investigations on several isothermal sections ${ }^{20-22)}$ and pseudo-binary sections $^{23-29)}$ were used to model the reciprocal system. All the reliable experimental data were successfully reproduced.

Cuspidine $\left(\mathrm{Ca}_{4} \mathrm{Si}_{2} \mathrm{~F}_{2} \mathrm{O}_{7}\right)$ is one of the most important crystalline phases in conventional mold fluxes. It crystallizes primarily from the molten mold flux and plays a significant role on the horizontal heat transfer control in the mold, which influences greatly the surface quality of the product. The Gibbs energy of cuspidine was measured by both the electromotive force (EMF) and the gas equilibration methods. ${ }^{30,31)}$ The optimized Gibbs energy of cuspidine phase is in good agreement with the experimental values within experimental error limits.

Figure 1 shows the calculated phase diagram of the cuspidine $\left(3 \mathrm{CaO} .2 \mathrm{SiO}_{2} \cdot \mathrm{CaF}_{2}\right)-\mathrm{CaF}_{2}$ section belonging to the $\mathrm{Ca}, \mathrm{Si} / / \mathrm{O}, \mathrm{F}$ reciprocal system. Watanabe et al. $^{29)}$ determined the liquidus and eutectic reaction of the cuspidine- $\mathrm{CaF}_{2}$ system using Differential Thermal Analysis (DTA) and classical quenching experiments in sealed Pt capsules followed by X-ray Diffraction (XRD) and Electron Probe MicroAnalysis (EPMA) phase identification. As seen in Fig. 1, the calculated phase diagram is in good agreement with the experimental data in the entire composition range. The calculated

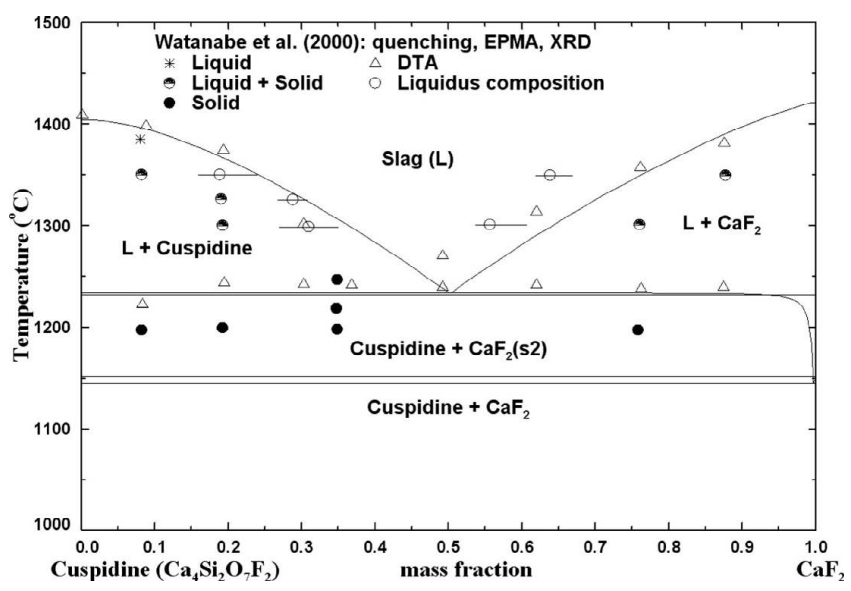

Fig. 1. Calculated pseudo-binary section between cuspidine $\left(\mathrm{Ca}_{4} \mathrm{Si}_{2} \mathrm{O}_{7} \mathrm{~F}_{2}\right)$ and $\mathrm{CaF}_{2}$ along with experimental data. ${ }^{29)}$

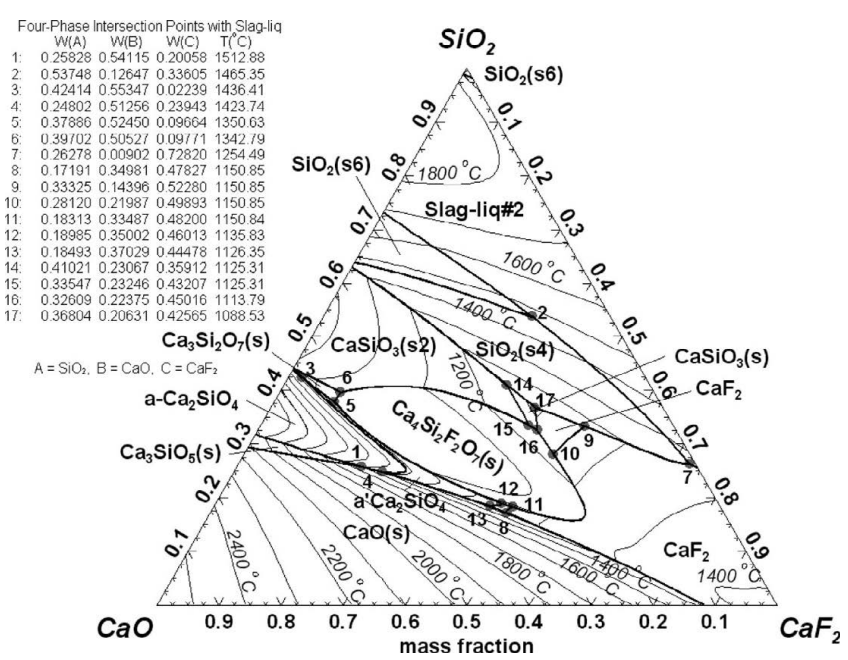

Fig. 2. Calculated liquidus projection for the $\mathrm{CaO}-\mathrm{SiO}_{2}-\mathrm{CaF}_{2}$ system. 
phase diagrams of other sections in the $\mathrm{Ca}-\mathrm{Si}-\mathrm{O}-\mathrm{F}$ system are also in good agreement with available reliable experimental results. ${ }^{23-29)}$ The present thermodynamic modeling can reproduce accurately both the experimental Gibbs energy and liquidus of cuspidine, which proves that the Gibbs energy of the liquid $\mathrm{CaO}-\mathrm{SiO}_{2}-\mathrm{CaF}_{2}-\mathrm{SiF}_{4}$ oxyfluoride phase is accurately described by the Two-sublattice Modified Quasichemical Model. The calculated liquidus projection of the $\mathrm{CaO}-\mathrm{SiO}_{2}-\mathrm{CaF}_{2}$ system, which is based on the present thermodynamic optimization using the most reliable thermodynamic and phase diagram data, is depicted in Fig. 2. The composition and temperature of the four-phase invariant reactions in the ternary $\mathrm{CaO}-\mathrm{SiO}_{2}-\mathrm{CaF}_{2}$ system predicted with the present thermodynamic database are summarized in Fig. 2.

\subsection{Equilibrium Solidification of Mold Flux}

The database can be applied to the accurate calculation of the equilibrium solidification of mold fluxes. An example of equilibrium solidification calculation is provided in Fig. 3, where a typical mold flux with composition (in $\mathrm{wt} \%$ ) 32.0 $\mathrm{SiO}_{2}, 36.7 \mathrm{CaO}, 0.7 \mathrm{MgO}, 6.8 \mathrm{Al}_{2} \mathrm{O}_{3}, 8.4 \mathrm{Na}_{2} \mathrm{O}$ and 15.4 $\mathrm{CaF}_{2}$ was employed. The calculation results predict that cuspidine $\left(\mathrm{Ca}_{4} \mathrm{Si}_{2} \mathrm{~F}_{2} \mathrm{O}_{7}\right)$ is the first compound to crystallize in the mold flux at approximately $1230^{\circ} \mathrm{C}$, which is in good agreement with experimental observations $\mathrm{s}^{32,33)}$ and predicted solidification and breaking temperatures. ${ }^{1,34)}$ As cuspidine continues precipitating from the liquid slag upon further cooling, the remaining liquid slag becomes richer in $\mathrm{MgO}$, $\mathrm{Na}_{2} \mathrm{O}$ and $\mathrm{Al}_{2} \mathrm{O}_{3}$, and eventually enters the solidification domain of $\mathrm{NCA}_{2}\left(\mathrm{Na}_{2} \mathrm{O} \cdot \mathrm{CaO} \cdot 2 \mathrm{Al}_{2} \mathrm{O}_{3}\right)$ and $\mathrm{Ca}_{3} \mathrm{MgSi}_{2} \mathrm{O}_{8}$. The predicted solidification behavior of many other commercial mold fluxes and new mold flux candidates were consistent with experimental data. The database can be effectively used to design new mold fluxes.

\section{Development of a Kinetic Model for Steel/Mold Flux Interactions}

\subsection{Effective Equilibrium Reaction Zone Model}

A kinetic model was developed to calculate the change in composition in molten slag during continuous casting by considering the reactions between molten slag and steel, and the absorption of non-metallic inclusions. The kinetic model is based on the Effective Equilibrium Reaction Zone Model

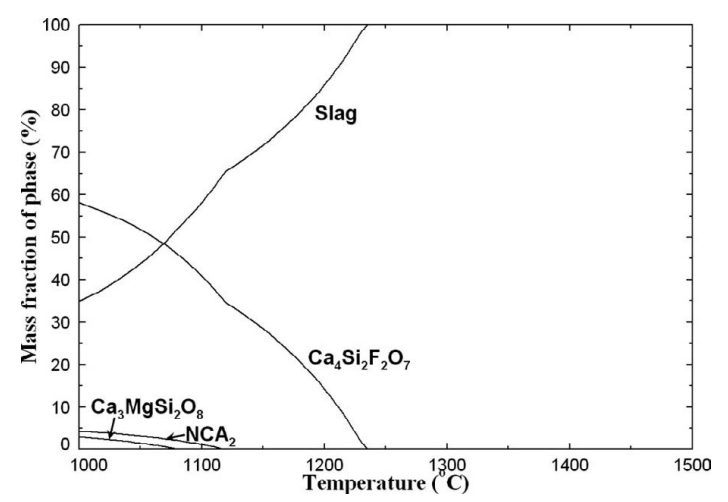

Fig. 3. Equilibrium solidification calculation of a typical mold flux. that was successfully applied to the RH degassing process. ${ }^{35)}$ In this approach, a complex process is divided in a finite number of reaction zones in which equilibrium are calculated. For instance, in the simplified case of a slag/metal reaction (Fig. 4), the metal phase would be divided in a bulk volume ( $\mathrm{V}_{1}$ in Fig. 4) and a smaller volume near the slag/ metal interface $\left(\mathrm{V}_{2}\right.$ in Fig. 4). The slag phase would be divided in a similar way $\left(\mathrm{V}_{3}\right.$ and $\mathrm{V}_{4}$ in Fig. 4). In the Effective Equilibrium Reaction Zone Model, the equilibrium would be first calculated between $V_{2}$ and $V_{3}$, followed by equilibrium homogenization reactions in the metal phase (between $\mathrm{V}_{1}$ and $\mathrm{V}_{2}$ ) and in the slag phase (between $\mathrm{V}_{3}$ and $\mathrm{V}_{4}$ ). Kinetics are taking into account by varying the reaction zone volumes depending on the process conditions, based on physical descriptions of the different reaction mechanisms. Simplified mathematical functions and empirical relations derived from simulations, experimental studies and plant data can be used to describe the effective reaction zone volumes. This approach allows easy linkage of the thermodynamic database to the kinetic simulation.

The schema of the effective reaction zones in the mold flux model is represented in Fig. 5. The mold slag pool was divided into three layers of different thickness and temperature to consider a temperature profile through the mold slag pool. The continuous fresh mold flux input into the upper mold slag layer (slag layer 3) and materials output from each mold slag layer were modeled by streams. A steel layer, which is continuously refreshed by steel from the steel pool, was reacted with the bottom slag layer (slag layer 1). The dissolution of non-metallic inclusions was conducted in the bottom slag layer (slag layer 1). In total, six reactions (R1 to R6 in Fig. 5) were created to simulate transport of matter and equilibrium reactions between the layers at each time step and are briefly described below:

- Reaction 1 (R1 in Fig. 5) represents the reaction

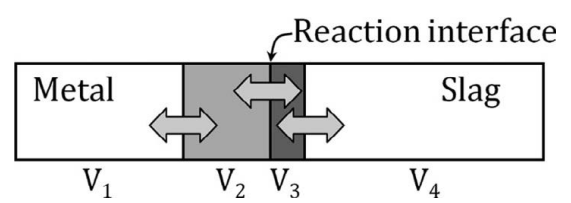

Fig. 4. Schematic representation of the reaction equilibrium model applied to a metal-slag reaction.

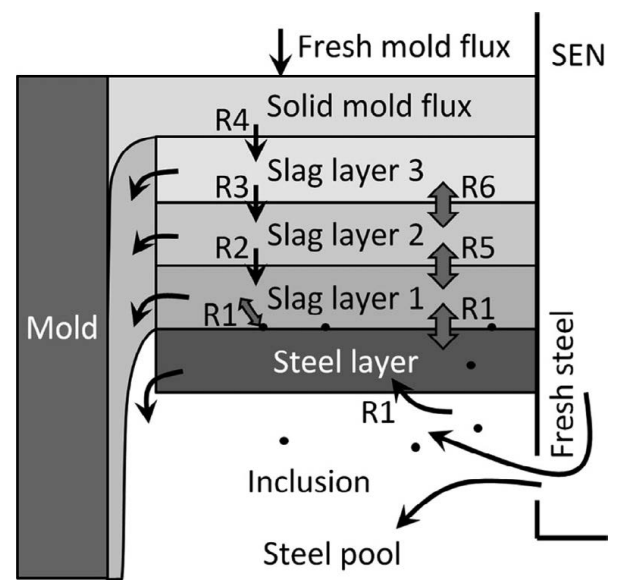

Fig. 5. Schematic representation of the reactions zones in the mold flux model. 
between the entire steel layer, the entire slag layer 1 and part of the inclusions. The amount of inclusion dissolved in slag layer 1 is defined by the inclusion removal fraction. The steel layer is also partially renewed by Fresh steel.

- Reactions 2 to 4 (R2 to R4 in Fig. 5) correspond to the downward material flow between and out of each slag layer. As Fresh mold flux is continuously added on top and the slag layer thicknesses are constant, material must enter and exit each slag layer at the same rate. In the present study, the amount of material exiting a given slag layer was assumed to be proportional to its thickness.

- Reactions 5 and 6 (R5 and R6 in Fig. 5) denote the partial homogenization between the slag layers. In the present study, it was assumed that $50 \%$ of a given slag layer is equilibrated with $50 \%$ of the neighboring layer.

The following assumptions were made:

- the temperature of slag layer 1 is identical to that of steel (casting temperature);

- the powder consumption is entirely due to the liquid mold flux layer moving downwards (i.e. no solid powder loss);

- the output rate of material from a slag layer is proportional to its thickness;

- the width and length of the slag and steel layers are those of the mold;

- the thickness of the slag and steel layers remains constant during the process;

- both liquid and solid phases take part in the reactions and material flow between layers. The fraction of liquid and solid are the same as in their layer of origin.

The equilibrium reactions R1 to R6 were calculated using the Equilib module in FactSage software ${ }^{18)}$ (version 6.3) and the accurate oxyfluoride database presented above. Streams with a given composition and temperature were created in FactSage to represent each slag layer, the steel layer, the non-metallic inclusions, and the fresh mold flux and fresh steel. These streams are used as reactants in the six equilibrium reaction calculations. For each of the six equilibrium reactions in the model, the appropriate reactants and their amount, possible reaction products (compounds and solutions) and final equilibrium conditions (temperature, pressure and other constraints) are entered in the Equilib module and saved as Equilib files. After each equilibrium reaction, the relevant streams are updated with the equilibrated phases obtained from the calculation. In this way, the updated streams can be easily imported to the next Equilib calculation. At each time step (fixed at $1 \mathrm{~min}$ ), the six equilibrium reactions are calculated consecutively after that the amount of fresh mold flux, fresh steel and non-metallic inclusions to be dissolved in the mold slag is determined based on the casting conditions. As the kinetic model involves large and repetitive Equilib calculations, the latter were automated by the macro processor integrated in FactSage. The scheme of the kinetic model is written as a series of commands in a macro file that enables editing and executing the Equilib files, saving the equilibrated phases as streams and writing the results of each equilibrium calculation in Microsoft Excel Worksheets.

\subsection{Simulation of Mold Flux Composition during the Casting of High Al Steel}

Recently, new steel grades with high $\mathrm{Al}$ and $\mathrm{Mn}$ content have been developed. One of the key problems encountered in the continuous casting of these steel grades is the poor casting performance usually observed with conventional $\mathrm{CaO}-\mathrm{SiO}_{2}$ type mold flux. High Al steel can interact with the mold flux, changing drastically its composition during the casting process.

Kim et $a l .{ }^{36)}$ performed laboratory-scale experiments to investigate reaction kinetics between $\mathrm{CaO}-\mathrm{SiO}_{2}$-based molten mold flux and high Mn steel (13 wt \% Mn) containing various $\mathrm{Al}$ concentration at temperatures between 1440 and $1550^{\circ} \mathrm{C}$. For example, about $400 \mathrm{~g}$ of high $\mathrm{Mn}$ steel $(\mathrm{Fe}-$ 0.65 C-1.77 Al-0.7 Si-13.2 Mn, in wt\%) was reacted with $44 \mathrm{~g}$ of conventional mold flux $\left(36.5 \mathrm{CaO}-33.6 \mathrm{SiO}_{2}-5.8\right.$ $\mathrm{Al}_{2} \mathrm{O}_{3}-2.5 \mathrm{MgO}-13.8 \mathrm{Na}_{2} \mathrm{O}-7.7 \mathrm{~F}$, in wt $\%$ ) at $1500^{\circ} \mathrm{C}$. They found that the reduction of $\mathrm{SiO}_{2}$ in slag by $\underline{\mathrm{Al}}$ occurred severely. The final (close to equilibrium state) slag contained about $30 \mathrm{wt} \% \mathrm{Al}_{2} \mathrm{O}_{3}$ and less than $20 \mathrm{wt} \% \mathrm{SiO}_{2}$, whereas the final steel contained about $2.0 \mathrm{wt} \% \mathrm{Si}$. Figure 6 shows the thermodynamic equilibrium calculations at $1500^{\circ} \mathrm{C}$ between the conventional mold flux and high $\mathrm{Mn}$ steel employed by Kim et al., ${ }^{36)}$ in which the initial Al content was varied from 0 to $5 \mathrm{wt} \%$. Figure 6 depicts the changes in the $\mathrm{Al}_{2} \mathrm{O}_{3}$ and $\mathrm{SiO}_{2}$ content in slag and the $\mathrm{Al}$ and $\mathrm{Si}$ content in molten iron after equilibrium with the initial Al content in molten iron. The thermodynamic calculations were performed with the same steel and slag amount reported by Kim et $a l^{36)}$ (400 and $44 \mathrm{~g}$, respectively). As can be seen in the calculation results, most of the $\mathrm{Al}$ in molten steel is consumed to reduce $\mathrm{SiO}_{2}$ in the mold flux according to Eq. (1).

$$
3 / 2\left(\mathrm{SiO}_{2}\right)+2 \underline{\mathrm{Al}}=\left(\mathrm{Al}_{2} \mathrm{O}_{3}\right)+3 / 2 \underline{\mathrm{Si}}
$$

As a result, the $\mathrm{Al}_{2} \mathrm{O}_{3}$ concentration increases in the molten mold flux, which can induce drastic changes in the solidification behavior of the mold flux and, consequently, severe difficulties in the horizontal heat flux control during the casting process. The final $\mathrm{Al}_{2} \mathrm{O}_{3}$ and $\mathrm{SiO}_{2}$ content in mold

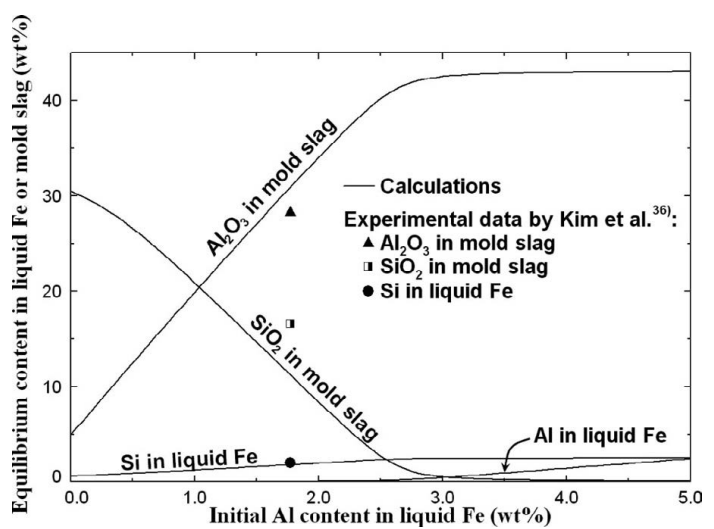

Fig. 6. Thermodynamic calculations between $44 \mathrm{~g}$ mold slag ( 36.5 CaO-33.6 $\mathrm{SiO}_{2}-5.8 \quad \mathrm{Al}_{2} \mathrm{O}_{3}-2.5 \quad \mathrm{MgO}-13.8 \quad \mathrm{Na}_{2} \mathrm{O}-7.7 \mathrm{~F}$, in $\mathrm{wt} \%$ ) and $400 \mathrm{~g}$ of high Mn steel (in wt $\%$ : Fe-0.65 C-0.7 Si13.2 $\mathrm{Mn}$ and $\mathrm{Al}$ content varying between 0 and $5 \mathrm{wt} \%$ ) at $1500^{\circ} \mathrm{C}$, and comparison with final $\mathrm{Al}_{2} \mathrm{O}_{3}, \mathrm{SiO}_{2}$ and $\mathrm{Si}$ content by $\mathrm{Kim}$ et al. ${ }^{36)}$ obtained experimentally with high $\mathrm{Mn}$ steel containing $1.77 \mathrm{wt} \% \mathrm{Al}$. 
slag and the final Si content in steel obtained by Kim et al. ${ }^{36)}$ with the initial $\mathrm{Al}$ content in steel of $1.77 \mathrm{wt} \%$ are compared with the calculations in Fig. 6. The thermodynamic calculation results show similar slag composition as obtained by Kim et al., ${ }^{36)}$ and $1.9 \mathrm{wt} \%$ final Si content in molten steel. Under the present calculation conditions (Fig. 6), it is theoretically possible to reduce almost all the $\mathrm{SiO}_{2}$ from the mold slag provided that enough $\mathrm{Al}$ is available in the steel. The $\mathrm{Al}_{2} \mathrm{O}_{3}$ content reaches then a maximum of about 43.0 wt $\%$. However, the calculation results in Fig. 6 do not consider kinetics or the fact that the cast steel and the mold slag are continually refreshed during the continuous casting process. Unfortunately, there is no exact equilibrium experimental data to compare with the present calculations.

To understand further the reactions between the molten mold flux and liquid steel in real casting process and predict the evolution of the molten mold flux composition with casting time, the kinetic model was applied to the casting of high Al steel. The molten steel/molten mold flux interactions were first simulated for a low-carbon steel with composition and casting conditions listed in Table 1, which are typically employed in industry. After $30 \mathrm{~min}$ of casting, the low-carbon steel was replaced by a high Al steel (Table 1). The mold flux presented in section 2.3 was employed for both steel grades and its equilibrium solidification was calculated in Fig. 3. The simulation parameters are listed in Table 1. The thickness of the mold slag pool was assumed to be $10 \mathrm{~mm}^{37)}$ The vertical temperature gradient was assumed to be $100^{\circ} \mathrm{C}$ through the mold slag pool. ${ }^{37)}$ The thickness of slag layer 1 was made smaller than the two others to obtain a steep temperature gradient in the mold slag pool near the steel surface. The steel layer thickness is a model parameter which influences the amount of $\mathrm{Al}_{2} \mathrm{O}_{3}$ accumulating in the mold slag. The thicker the steel layer, the more $\mathrm{Al}$ gets in contact with slag layer 1, the higher the $\mathrm{Al}_{2} \mathrm{O}_{3}$ accumulation in the mold slag. As it cannot be directly measured, the steel layer thickness was assumed to be half that of the mold slag. Both steel grades were assumed to contain about $20 \mathrm{ppm} \mathrm{Al}_{2} \mathrm{O}_{3}$ inclusions with a fixed removal rate of $15 \%$.

The predicted evolution of the bottom slag layer composition (slag layer 1 in Fig. 5) and steel layer composition as a function of casting time is shown in Figs. 7(a) and 7(b), respectively. During the low-carbon steel casting, a moder- ate increase of the $\mathrm{Al}_{2} \mathrm{O}_{3}$ content and a decrease of the $\mathrm{SiO}_{2}$ content in the slag layer 1 were predicted. The $\mathrm{Al}_{2} \mathrm{O}_{3}$ concentration in the molten slag increased quickly during the initial stage and gradually approached a steady-state value of $10.9 \mathrm{wt} \% \mathrm{Al}_{2} \mathrm{O}_{3}$ after approximately $15-20$ min of casting (Fig. 7(a)). In the steel layer (Fig. 7(b)), the Al content decreased from 500 to $\sim 6.4 \mathrm{ppm}$, whereas $\mathrm{Si}$ increased from 0.04 to $0.084 \mathrm{wt} \%$. As seen in Fig. 7(a), the high Al content in steel casted after 30 min induced a significant increase of the $\mathrm{Al}_{2} \mathrm{O}_{3}$ content and a significant decrease of $\mathrm{SiO}_{2}$ in the molten mold slag. Similar to the low-carbon steel case, the $\mathrm{Al}_{2} \mathrm{O}_{3}$ content in molten mold slag increased quickly during the initial stage and gradually approaches a steady state of $31.9 \mathrm{wt} \% \mathrm{Al}_{2} \mathrm{O}_{3}$ after approximately $15-20$ min casting. In the steel layer (Fig. 7(b)), the Si content has increased from 0.9 to $1.23 \mathrm{wt} \%$, whereas $\mathrm{Al}$ decreased from 2 to $1.55 \mathrm{wt} \%$. The predicted composition of slag layers 2 and 3 shows the same trend, but it takes a couple of min more to reach the steady state and a lower steady state $\mathrm{Al}_{2} \mathrm{O}_{3}$ concentration is obtained. This is because the changes in slag composition in layers 2 and 3 occur gradually with the propagation of the changes in layer 1 to layers 2 and 3 . The evolution of the overall slag composition (average of slag layers 1, 2 and 3) with casting time is plotted in Fig. 7(c). The steady state is reached after about 15-20 min following the transition from the low-carbon steel to the high Al steel. The steady state $\mathrm{Al}_{2} \mathrm{O}_{3}$ content in the overall slag is about $16.5 \mathrm{wt} \%$.

In both steel grades, the reaction between steel and mold slag pool and the dissolution of $\mathrm{Al}_{2} \mathrm{O}_{3}$ inclusions in the slag pool caused an increase in the $\mathrm{Al}_{2} \mathrm{O}_{3}$ content and a decrease of the $\mathrm{SiO}_{2}$ content, suggesting the global reaction between steel and slag to be given by Eq. (1). The reaction mechanism that is proposed by the present simulations is in good agreement with that suggested in literature ${ }^{2,3,36,38)}$ since the model is built by combining kinetic expressions with an accurate thermodynamic database. Unfortunately, no mold flux study in the transition period of molten steel has been reported. More remarkably, the model can reproduce the observed characteristics of the $\mathrm{Al}_{2} \mathrm{O}_{3}$ accumulation with casting time: a fast increase of the $\mathrm{Al}_{2} \mathrm{O}_{3}$ content followed by a steady state. ${ }^{2,3)}$ The predicted steady state value and the time required to reach it are also in good agreement with experimental results ${ }^{2,3}$ ) $\left(25\right.$ to $35 \mathrm{wt} \% \mathrm{Al}_{2} \mathrm{O}_{3}$ within $15 \mathrm{~min}$ with various $\mathrm{Al}$ content in steel, casting conditions and mold

Table 1. Mold dimensions, simulation parameters and casting conditions employed in the kinetic model.

\begin{tabular}{|c|c|c|c|c|c|c|c|c|c|}
\hline \multicolumn{2}{|c|}{$\begin{array}{l}\text { Mold dimensions } \\
\qquad(\mathrm{mm})\end{array}$} & \multicolumn{8}{|c|}{ Simulation parameters } \\
\hline Length & 900 & & $\begin{array}{l}\text { Thickness } \\
(\mathrm{mm})\end{array}$ & $\begin{array}{c}\text { Temperature } \\
\left({ }^{\circ} \mathrm{C}\right)\end{array}$ & & \multicolumn{2}{|c|}{$\begin{array}{l}\text { Thickness } \\
(\mathrm{mm})\end{array}$} & \multicolumn{2}{|c|}{$\begin{array}{c}\text { Temperature } \\
\left({ }^{\circ} \mathrm{C}\right)\end{array}$} \\
\hline Width & 1500 & Slag layer 1 & 1 & 1550 & Slag layer 3 & \multicolumn{2}{|c|}{5} & \multicolumn{2}{|c|}{1450} \\
\hline Thickness & 250 & Slag layer 2 & 4 & 1500 & Steel layer & \multicolumn{2}{|c|}{5} & \multicolumn{2}{|c|}{1550} \\
\hline \multicolumn{10}{|c|}{ Casting conditions } \\
\hline \multirow{2}{*}{\multicolumn{2}{|c|}{ Steel grade }} & \multirow{2}{*}{$\begin{array}{l}\text { Casting time } \\
\text { (min) }\end{array}$} & \multirow{2}{*}{$\begin{array}{l}\text { Casting } \\
\text { speed } \\
\left(\mathrm{m} \mathrm{min}{ }^{-1}\right)\end{array}$} & \multirow{2}{*}{$\begin{array}{c}\text { Casting } \\
\text { temperature } \\
\left({ }^{\circ} \mathrm{C}\right)\end{array}$} & \multirow{2}{*}{$\begin{array}{c}\text { Powder } \\
\text { consumption } \\
\left(\mathrm{kg} \mathrm{m}^{-2}\right)\end{array}$} & \multicolumn{4}{|c|}{ Steel composition (wt\%) } \\
\hline & & & & & & $\mathrm{Mn}$ & $\mathrm{Si}$ & $\mathrm{C}$ & Al \\
\hline \multicolumn{2}{|c|}{ Low C steel } & $0-30$ & 1.1 & 1550 & 0.4 & 0.9 & 0.04 & 0.01 & 0.05 \\
\hline \multicolumn{2}{|c|}{ High Al steel } & $31-60$ & 0.8 & 1550 & 0.5 & 13.1 & 0.9 & 0.01 & 2.0 \\
\hline
\end{tabular}



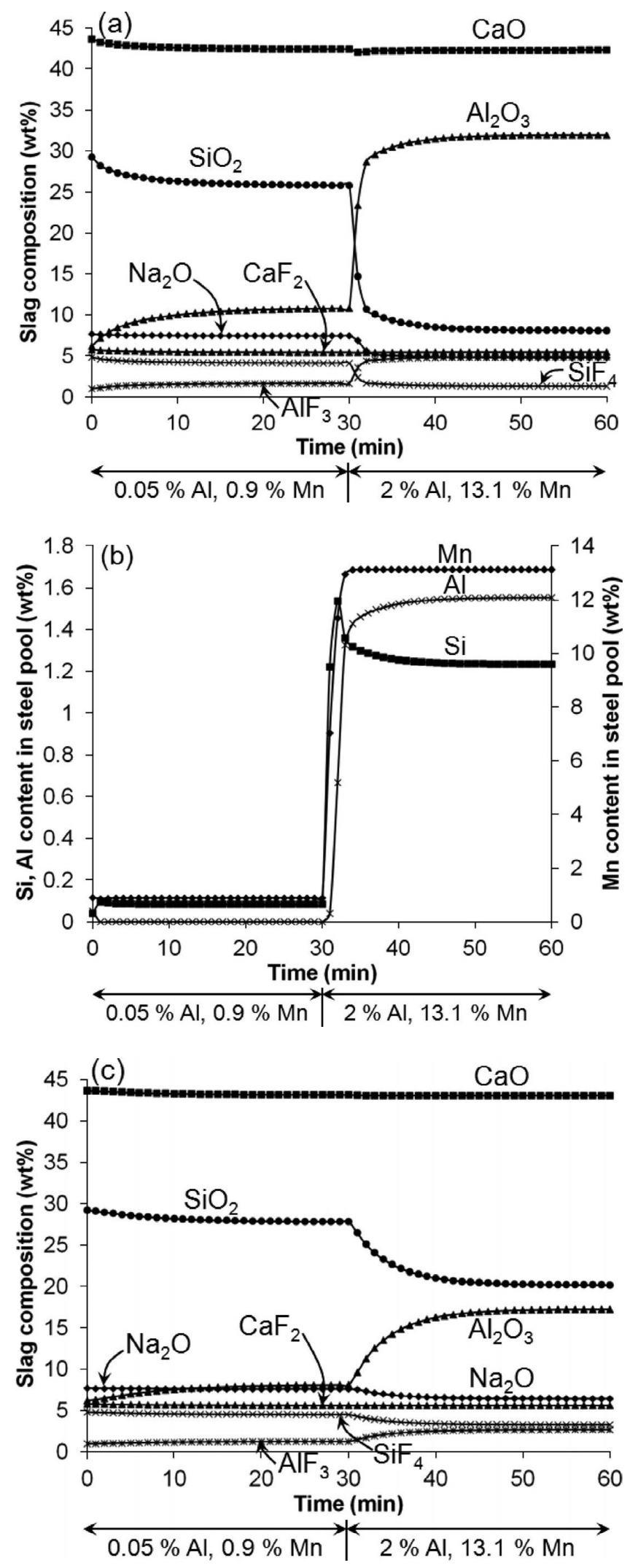

Fig. 7. Evolution of the calculated composition of (a) bottom slag layer (Slag layer 1), (b) steel layer and (c) overall slag layer with casting time.

flux composition).

Owing to the drastic changes in the mold slag pool composition after casting high $\mathrm{Al}$ steel, the viscosity, heat transfer and performance of the mold flux is expected to be very different from the original one. To illustrate such changes,
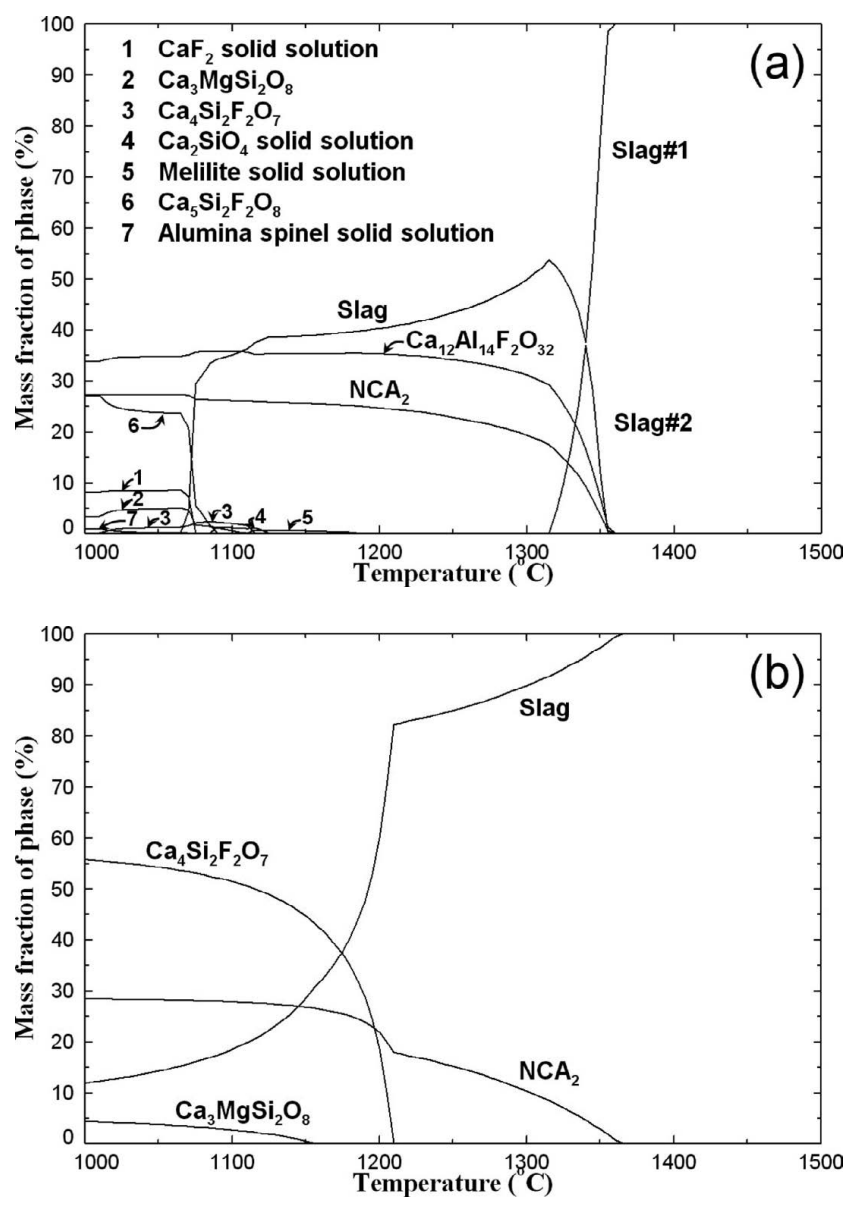

Fig. 8. Equilibrium solidification calculation of (a) slag layer 1 and (b) the average mold slag obtained after high Al steel casting.

the equilibrium solidification, after reaction with the high $\mathrm{Al}$ steel (steady state), of the bottom slag layer (slag layer 1) and that of the average mold slag pool were calculated in Figs. 8(a) and 8(b), respectively. As seen in Fig. 7(a), slag layer 1 contains approximately $32 \mathrm{wt} \% \mathrm{Al}_{2} \mathrm{O}_{3}$ and $8 \mathrm{wt} \%$ $\mathrm{SiO}_{2}$ after reaction with the high $\mathrm{Al}$ steel (against $6.8 \mathrm{wt} \%$ $\mathrm{Al}_{2} \mathrm{O}_{3}$ and $32 \mathrm{wt} \% \mathrm{SiO}_{2}$ in the original mold flux). The average mold slag pool composition, which was obtained by homogenizing the three mold slag layers after reaction with the high $\mathrm{Al}$ steel, contains $16.5 \mathrm{wt} \% \mathrm{Al}_{2} \mathrm{O}_{3}$ and $20.8 \mathrm{wt} \%$ $\mathrm{SiO}_{2}$ (Fig. 7(c)). Due to the compositional change, the solidification behavior of the two altered molten mold fluxes shown in Fig. 8 is very different from the original mold flux (Fig. 3). In both cases, the solidification temperature has increased from 1230 to $1360^{\circ} \mathrm{C}$ and the primary phase has shifted from cuspidine to an $\mathrm{Al}_{2} \mathrm{O}_{3}$-rich compound. The compounds $\mathrm{Ca}_{12} \mathrm{Al}_{14} \mathrm{~F}_{2} \mathrm{O}_{32}\left(11 \mathrm{CaO} \cdot 7 \mathrm{Al}_{2} \mathrm{O}_{3} \cdot \mathrm{CaF}_{2}\right)$ and $\mathrm{Na}_{2} \mathrm{O} \cdot \mathrm{CaO} \cdot 2 \mathrm{Al}_{2} \mathrm{O}_{3}\left(\mathrm{NCA}_{2}\right.$, which forms a solid solution with $\mathrm{Na}_{2} \mathrm{O} \cdot \mathrm{Al}_{2} \mathrm{O}_{3}$ ) crystallize first from the liquid slag layer 1 (Fig. 8(a)), whereas $\mathrm{NCA}_{2}$ forms first from the average mold slag (Fig. 8(b)). As seen in Fig. 8(a), the liquid slag in slag layer 1 splits into two immiscible liquids between 1360 and $1310^{\circ} \mathrm{C}$ and the liquid disappears below $1065^{\circ} \mathrm{C}$. In the case of the average mold slag (Fig. 8(b)), the $\mathrm{SiO}_{2}$ content is high enough $(\sim 20 \mathrm{wt} \%)$ to maintain the precipitation of cuspidine around $1210^{\circ} \mathrm{C}$ and preserve it as the main crystal phase. The evolution of the liquid fraction with temperature decreases sharply below $1200^{\circ} \mathrm{C}$. Such drastic changes cer- 
tainly have detrimental effects on the casting performance.

Recent studies by Marschall et al. ${ }^{39)}$ and Wang et al. ${ }^{40)}$ on industrial mold flux film analysis for high $\mathrm{Al}$ steel show that the large $\mathrm{Al}_{2} \mathrm{O}_{3}$ pickup in the mold slag due to the reduction of $\mathrm{SiO}_{2}$ by $\mathrm{Al}$ in steel can result in the formation of more $\mathrm{Al}_{2} \mathrm{O}_{3}$ containing crystals $\left(\mathrm{Na}_{2} \mathrm{O}-\mathrm{Al}_{2} \mathrm{O}_{3}-\mathrm{SiO}_{2}-\mathrm{CaO}\right)$ instead of cuspidine crystal which is found in conventional mold flux for low carbon steel (see Fig. 3). The present calculations in Fig. 8 agree with these results reported from plant operation.

\section{Summary}

An accurate and consistent thermodynamic database for the $\mathrm{CaO}-\mathrm{MgO}-\mathrm{Al}_{2} \mathrm{O}_{3}-\mathrm{SiO}_{2}-\mathrm{Na}_{2} \mathrm{O}-\mathrm{K}_{2} \mathrm{O}-\mathrm{Li}_{2} \mathrm{O}-\mathrm{MnO}-\mathrm{FeO}-$ $\mathrm{F}$ mold flux system was built. The liquid oxyfluoride phase is described using the Two-sublattice Modified Quasichemical Model, which can accurately represent its thermodynamic properties. All reliable experimental data could be reproduced within experimental error, as was illustrated with the $\mathrm{CaO}-\mathrm{SiO}_{2}-\mathrm{CaF}_{2}$ system in the present study. Accurate equilibrium solidification calculations for a wide range of mold flux can be performed. In the future, the thermodynamic database will be expanded to $\mathrm{ZrO}_{2}, \mathrm{TiO}_{\mathrm{x}}, \mathrm{S}, \mathrm{H}$, etc. to cover a wider range of casting applications.

A kinetic model was developed to simulate the changes in the molten mold flux composition with casting conditions. The model is based on the effective reaction zone approach and combines the thermodynamic database with kinetics. Simulation of the interactions between the mold slag and the molten steel was carried out for a low-carbon and a high Al steel. The kinetic model can successfully reproduce the significant $\mathrm{Al}_{2} \mathrm{O}_{3}$ accumulation in the mold slag observed when casting high $\mathrm{Al}$ steel with $\mathrm{CaO}-\mathrm{SiO}_{2}$ type mold flux. The equilibrium solidification calculations performed on the $\mathrm{Al}_{2} \mathrm{O}_{3}$-rich mold slag revealed drastic changes in its solidification behavior, causing significant loss of casting performance.

\section{Acknowledgements}

Financial support from Hyundai Steel, JFE Steel Corporation, Nippon Steel \& Sumitomo Metal, Nucor Steel, Posco, QIT, RHI, RIST, Tata Steel Europe, Voest Alpine and the Natural Science and Engineering Research Council of Canada (NSERC) is gratefully acknowledged. The authors would like to express their gratitude to Prof. Jung-Wook Cho, GIFT, Postech, for the valuable discussions during the progress of this study.

\section{REFERENCES}

1) K. C. Mills, A. B. Fox, Z. Li and R. P. Thackray: Ironmaking
Steelmaking, 32 (2005), 26.

2) Q. Wang, S. Qiu and P. Zhao: Metall. Mater. Trans. B, 43 (2012), 424.

3) X. Yu, G.-H. Wen, P. Tang, F.-J. Ma and H. Wang: J. Iron Steel Res. Int., 18 (2011), 20.

4) I.-H. Jung: Proc. Asia Steel Conf., The Korean Institute of Metals and Materials, Seoul, South Korea, (2009), S3/30.

5) I.-H. Jung: Proc. AISTech 2010, Association for Iron \& Steel Technology, Warrendale, PA, (2010), 1211.

6) I.-H. Jung, M.-A. Van Ende and D.-G. Kim: Proc. UNITECR 2011, The Technical Association of Refractories, Tokyo, (2011), 582.

7) D.-G. Kim, M.-A. Van Ende, C. Van Hoek, C. Liebske, S. Van Der Laan and I.-H. Jung: Metall. Mater. Trans. B, 43 (2012), 1315.

8) D.-G. Kim, C. van Hoek, C. Liebske, S. van der Laan, P. Hudon and I.-H. Jung: ISIJ Int., 52 (2012), 1945.

9) A. D. Pelton, S. A. Decterov, G. Eriksson, C. Robelin and Y. Dessureault: Metall. Mater. Trans. B, 31 (2000), 651.

10) A. D. Pelton and P. Chartrand: Metall. Mater. Trans. A, 32 (2001), 1355.

11) G. Eriksson and A. D. Pelton: Metall. Trans. B, 24 (1993), 807.

12) I.-H. Jung: PhD Thesis, Ecole Polytechnique, Montreal, Canada, (2003).

13) S. A. Decterov, I.-H. Jung, E. Jak, Y. B. Kang, P. Hayes and A. D. Pelton: Proc. VII Int. Conf. on Molten Slags, Fluxes and Salts, The South African Institute of Mining and Metallurgy, Johannesburg, (2004), 839.

14) I.-H. Jung, S. A. Decterov and A. D. Pelton: Metall. Mater. Trans. $B, 35$ (2004), 877.

15) I.-H. Jung, S. A. Decterov and A. D. Pelton: J. Phase Equilib. Diffus., 25 (2004), 329.

16) I.-H. Jung, S. A. Decterov and A. D. Pelton: J. Am. Ceram. Soc., 88 (2005), 1921.

17) I.-H. Jung, S. A. Decterov and A. D. Pelton: J. Eur. Ceram. Soc., 25 (2005), 313.

18) C. W. Bale, E. Belisle, P. Chartrand, S. A. Decterov, G. Eriksson, K. Hack, I. H. Jung, Y. B. Kang, J. Melancon, A. D. Pelton, C. Robelin and S. Petersen: Calphad, 33 (2009), 295.

19) P. Chartrand and A. D. Pelton: Metall. Mater. Trans. A, 32 (2001), 1397.

20) R. Selin, Y. Dong and Q. A. Wu: Scand. J. Metall., 19 (1990), 98.

21) A. I. Zaitsev, M. A. Zemchenko, A. D. Litvina and B. M. Mogutnov: J. Mater. Chem., 3 (1993), 541.

22) T. Watanabe, H. Fukuyama and K. Nagata: ISIJ Int., 42 (2002), 489.

23) T. Baak and A. Olander: Acta Chem. Scand., 9 (1955), 1350.

24) J. Mukerji: Mem. Sci. Rev. Metall., 60 (1963), 785

25) J. Mukerji: J. Am. Ceram. Soc., 48 (1965), 210.

26) Y. Shiraishi and T. Saito: Nippon Kinzoku Gakkaishi, 29 (1965), 622.

27) W. H. Gutt and G. J. Osborne: Trans. Br. Ceram. Soc., 65 (1966), 521.

28) H. Suito and D. R. Gaskell: Metall. Trans. B, 7 (1976), 567.

29) T. Watanabe, H. Fukuyama, M. Susa and K. Nagata: Metall. Mater. Trans. B, 31 (2000), 1273.

30) H. Fukuyama, H. Tabata and K. Nagata: Metall. Mater. Trans. B, 34 (2003), 307.

31) H. Fukuyama, H. Tabata, T. Oshima and K. Nagata: ISIJ Int., 44 (2004), 1488.

32) M. Hanao, M. Kawamoto and T. Watanabe: ISIJ Int., 44 (2004), 827.

$33)$ R. G. Hill, N. Da Costa and R. V. Law: J. Non-Cryst. Solid., 351 (2005), 69

34) S. Sridhar, K. C. Mills, O. D. C. Afrange, H. P. Lörz and R. Carli: Ironmaking Steelmaking, 27 (2000), 238.

35) M.-A. Van Ende, Y.-M. Kim, M.-K. Cho, J. Choi and I.-H. Jung: Metall. Mater. Trans. B, 42 (2011), 477.

36) M.-S. Kim, S.-W. Lee, J.-W. Cho, M.-S. Park, H.-G. Lee and Y.-B. Kang: Metall. Mater. Trans. B, 44 (2013), 299.

37) J.-W. Cho: personnal communication, (2013).

38) Y.-B. Kang, M.-S. Kim, S.-W. Lee, J.-W. Cho, M.-S. Park and H.G. Lee: Metall. Mater. Trans. B, 44 (2013), 309.

39) I. Marschall, N. Kölbl, H. Harmuth and G. Xia: J. Manuf. Sci. Prod., 13 (2013), 103

40) W. Wang, K. Blazek and A. Cramb: Metall. Mater. Trans. B, 39 (2008), 66 